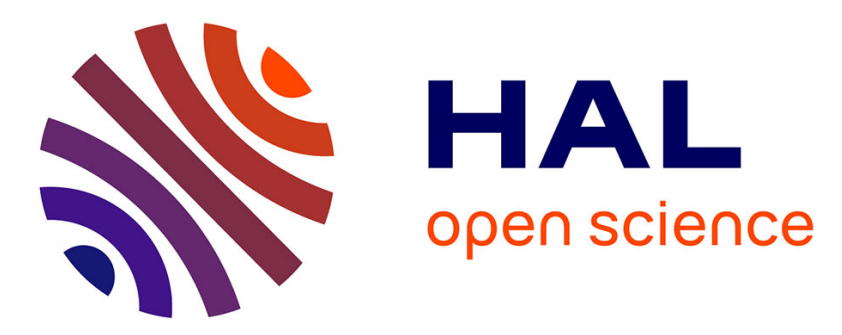

\title{
Changing nature and sustainability of the industrial district model: the case of Technic Valley in France
}

Michel Barabel, Isabelle Huault, Olivier Meier

\section{To cite this version:}

Michel Barabel, Isabelle Huault, Olivier Meier. Changing nature and sustainability of the industrial district model: the case of Technic Valley in France. Growth and Change, 2007, 38 (4), pp.595-620. 10.1111/j.1468-2257.2007.00389.x . halshs-00150765

\section{HAL Id: halshs-00150765 \\ https://shs.hal.science/halshs-00150765}

Submitted on 29 Jul 2010

HAL is a multi-disciplinary open access archive for the deposit and dissemination of scientific research documents, whether they are published or not. The documents may come from teaching and research institutions in France or abroad, or from public or private research centers.
L'archive ouverte pluridisciplinaire $\mathbf{H A L}$, est destinée au dépôt et à la diffusion de documents scientifiques de niveau recherche, publiés ou non, émanant des établissements d'enseignement et de recherche français ou étrangers, des laboratoires publics ou privés. 


\title{
Changing nature and sustainability of the industrial district model: the case of Technic Valley in France ${ }^{1}$
}

\author{
Michel Barabel, University Paris 12, IRG/ LARA-ICD \\ Isabelle Huault, University Paris Dauphine, DRM-DMSP \\ Olivier Meier, University Paris 12, IRG/ LARA-ICD
}

\begin{abstract}
This paper examines the impact of contemporary pressures on industrial districts and analyses the changes that are taking place in an industrial district confronted with disembedding and globalization. We discuss the following questions: what are the processes and consequences of disembedding for the changing shape and form of inter-firm trust, contract and network forms? Is there an evolution in subcontracting and trade interdependency? What is the role of institutional infrastructures? We performed a longitudinal qualitative study using a number of different data sources to analyse the evolution of one French industrial district, particularly how new pressures of internationalization and disembedding work to reconfigure inter-firm relations in this district.

While the recent literature is dominated by notions about industrial districts that concern only the trend towards increased competition or disembeddedness, this article shows that there is no unilinear trend. In contrast with the findings of certain recent studies, we argue that economic logic does not fully account for recent developments since the adjustment that are being made by the district are characterized rather by re-embeddedness, increased cooperation and institutionalization.
\end{abstract}

\footnotetext{
${ }^{1}$ The order of authors is alphabetical, reflecting their equal contribution.
} 


\section{Introduction}

Industrial districts have long been considered an alternative form of economic development (Piore \& Sabel, 1984). They have been defined as small territories in which a high concentration of specialised independent companies within the same sector embark upon long-term cooperation, often on a fairly informal basis, founded on relationships of solidarity and trust between the members within the district, and with the support of local institutions such as universities, industry, politicians or trade associations (Becattini and Sengenberger, 1990; Dei Ottati, 1994).

However, this canonical view of industrial districts has tended to be called into question both theoretically and empirically (Paniccia, 1998) and now contains conflicting visions (Whitford, $2001)^{2}$. In view of the contemporary pressures to which such districts are subjected, a number of authors (Lorenzen and Mahnke, 2002; Nassimbeni, 2003, Camuffo, 2003) insist on a movement towards increased competition and disembedding of industrial districts. In keeping with this strand of the literature, our paper aims to show how the organisation of firms and institutions in the district has changed over time and how more recent changes, particularly under the pressure of globalisation, have served to transform economic and social activity. The following questions are discussed: what are the processes and consequences of disembedding for the changing shape and form of inter-firm trust, contract and network forms? Is there a change in subcontracting and trade interdependency? What is the changing role of institutional infrastructures?

We suggest that the industrial districts have undergone significant changes over time as a function of historical context or factors such as the economic climate, the advent of multinational firms and technological change. However, in contrast with recent works on these issues that focus on increased competition and disembeddedness in industrial districts faced with new events (Grabher, 1993; Lazerson and Lorenzoni, 1999; Biggiero, 2002) and that fail to point out that the contrary tendency may also be observed as a result of contextual factors, we argue that there is no unilinear 
trend. We show in particular that economic logic does not account fully for developments seen in recent times, since the adjustments made by the district are characterized rather by reembeddedness, increased cooperation and institutionalization.

Our analysis is based on a longitudinal qualitative study and on data collected from several sources and in particular extensive semi-structured interviews with the main actors in one significant French industrial district: Technic Valley. The results of these interviews were combined with detailed analysis of secondary data; mainly historical archives, resulting in a "thick description" of the industrial district.

The remainder of the paper is organized as follows: the first section explores the concept of industrial districts with regard to existing literature and focuses attention simultaneously on the role of cooperation and competition, embeddedness and disembeddedness. The second section describes the methodology, the third presents our case study and the fourth discusses our key results by linking the study to policy debates.

\section{Previous exploration of the notion of the industrial district}

In this section, we present the canonical view of industrial districts, with the accent on predominance of cooperation and embeddedness (1.1). However, studies concerned with the changing nature of industrial districts tend to insist on disembeddedness and increasingly strong market forces. According to this line of research, in the long run, reciprocity and relationships based on trust disappear while market-based relationships increase (1.2).

\section{The canonical literature on industrial districts: embeddedness and cooperation.}

While industrial districts possess an undeniable economic dimension, they also form part of singular social systems in which solidarity plays an important role. The markets are organised in the form of networks of contacts in such a way that economic transactions and social relations are

\footnotetext{
${ }^{2}$ For example, Whitford explains that there remains extensive disagreement between authors over appropriate public policies. The most crucial issues are questions about the adequacy of the districts regulatory and service institutions in overcoming the structural
} 
completely embedded in social relations. In industrial districts, managers of small and mediumsized businesses based within a common social and cultural environment frequently share similar outlooks and social values. The fact that the various players involved operate within a small geographical territory results in closeness due to frequent informal interaction and potentially in relations based on friendship. The key features differentiating a more "thickly" defined industrial district from network production are generally an abundance of local productive knowledge, strong institutions and a culture that facilitates cooperation, leading to enhanced information flow and lower transaction costs (Whitford, 2001: 41). As Scott and Storper (2003: 583) stress, “considerable gains in productivity typically flow to firms from this localized concentration of many different suppliers and buyers." In particular, companies can maintain low overheads while achieving high flexibility in both internal and external operations. In conclusion, Scott and Storper (2003) state that geographical concentration lowers the costs of transactions, raises the probability of successful matching for all parties and allows the establishment of mutual confidence between partners in business relationships. In this respect, another important point is to maintain a collective identity (Porac, Thomas and Baden-Fuller, 1989), as well as upholding the rules of membership and of the social network, which override considerations of optimal economic performance.

Considerations of loyalty and maintaining a reputation that has been built up within structures regarded as "community-based" thus appear to be of crucial importance (Becattini, 1990, 1991; Brusco, 1990, Dei Ottati, 1994, Mistri and Solari, 2002). Social networks and proximity create a dense atmosphere for the diffusion of role models that lead to a self-reinforcing process. They facilitate the transfer of tacit and specialized knowledge (Lechner and Dowling, 1999).

Moreover, local institutions play a major role in defusing crises that could potentially threaten an industrial district (Piore and Sabel, 1984; Pyke, Becattini and Sengenberger, 1990; Coro and Grandinetti, 1999; Molina-Morales et al., 2002). These rich networks of institutional partners, local infrastructures, training companies and dedicated service providers render the environment particularly propitious for the creation and viability of companies. In conclusion, trust nurtured by 
continuity of informal relations and the mediation of institutions close to the actors involved appear to form a vital component of local development.

To all of the foregoing characteristics must be added the territorial aspect. This inter-firm cooperation is found in economic activities centred upon a particular region. Geographical agglomerations benefit firms in the form of positive externalities or non-tradable interdependencies (Storper, 1997 ; Scott, 1998, 2006). Reciprocity implies close spatial relations. In this perspective, geographical proximity often overlaps and combines with institutional, organizational and technical proximity in fostering processes of collective learning (Breschi and Malerba, 2001; Perez-Aleman, 2005).

Finally, industrial districts benefit from a common culture and social networks ensure economic cooperation.

However, while the canonical literature insists more on the importance of the community character, these districts are not analysed simply in monolithic terms since a number of recent studies highlight their competitive character and the disembedding process.

\section{Industrial districts and disembeddedness}

As Boschma and Lambooy (2002: 299) explain, there is a growing literature that calling into question the ideal-type characterization of industrial districts. They stress that local production systems are confronted with increasing globalization of the economy and have gone through a process of transition in which their market structure may have changed.

In this respect, why industrial districts are different and make different choices depends largely on shifts in supply and demand, technological flow and globalization (Lazerson and Lorenzoni, 1999; Amighini and Rabelotti, 2006). According to the authors, these relationships in themselves demonstrate gradual and ineluctable disembeddedness.

Disembeddedness refers to transition from reasoning based on social relationships to more commercially oriented reasoning, and change towards increased competition that gradually wipes out former ties of solidarity, or again, leads to decreased attachment of entrepreneurs to a specific 
area as a result of focusing on the purely financial aspects of their activity. In this context, there is less interactive and inter-organizational learning in the district, since the market concentration process has some consequences for the collective learning process in industrial districts (Boschma and Lambooy, 2002: 301). Bellini (2000) suggests more generally that the cooperative institutional environment is increasingly under pressure and that many institutions have in fact lost their significance.

Thus, Ganne (1991: 556) notes that in France, the dynamics of districts appear to be characterised chiefly by "the decline and disappearance of older systems", with the result that diffuse industrial systems such as the Italian model remain the exception. He places greater emphasis on recomposition within the systems of small and medium sized businesses, while underlining the historically, culturally and politically relevant character of the districts, which may disappear whatever the strength of the prevailing local structures. Furthermore, where shared institutions or the configuration of the social networks play a significant role within districts, they occasionally lose their influence or risk being dismantled as a result of unforeseen events. In her study, Paniccia (1998) noted the emergence of processes of rationalisation in all of the districts she analysed: the arrival of new companies, often large, as well as merger and acquisition in a context of globalisation, or the deviant behaviour of certain participants, led to a decrease in the number of companies and employees present. This trend results in a unified form of exchange dominated by competition, market mechanisms (Campbell and Pedersen, 2001) and deterritorialization (Scholte, 2000). This corresponds to the breaking up of the territory as a fundamental dimension of social life and social interactions (Held et al., 1999: 16). Market relations are universalistic and the same rules apply among contractors without specific considerations related to geographical proximity or longstanding relations.

Takeovers by outside multinational corporations are for example an "invasion" that qualitatively transforms "the nonhierarchical, collaboratively competitive nature of interfirm relations within the districts" (Whitford, 2001: 47). Under these conditions, relationships built upon trust can be reduced to relationships based purely on power and competition (Lorenzen and Mahnke, 2002; 
Phelps and Waley, 2004). Multinational companies are generally able to turn internal skills within a district to their own advantage, underscoring once more the vulnerability of districts forced to watch large companies take advantage of local knowledge and expertise whilst severely disrupting the preexisting models of social relationships. What many authors (Camuffo, 2003) ultimately demonstrate is that, as a result of globalization, networks of socially embedded, local-based small- and mediumsized companies do not represent organizational structures as robust and stable as their forerunners. Globalization challenges networks and demands adjustments that transform the nature of industrial districts (Rama et al., 2003; Dunford, 2006).

Table 1 shows what is understood by embeddedness and disembeddedness, "cooperation" and "competition" in order to better explain "what types of behaviour, which actions exactly are competitive and which are cooperative" (Markusen, 2003: 710).

\section{TABLE 1. COOPERATION AND COMPETITION, EMBEDDEDNESS AND DISEMBEDDEDNESS IN INDUSTRIAL DISTRICTS}

\begin{tabular}{|c|c|}
\hline Cooperation/ Embeddedness & Competition/ Disembeddedness \\
\hline $\begin{array}{l}\text { Embeddedness } \\
\text { - } \quad \text { Territory as a fundamental dimension of } \\
\text { social life and social interactions. Spatially } \\
\text { clustered relations } \\
\text { - } \quad \text { Social networks } \\
\text { - } \quad \text { Trust, solidarity } \\
\text { - } \quad \text { Common culture } \\
\text { - }\end{array}$ & $\begin{array}{l}\text { Disembeddedness } \\
\text { - } \quad \text { Entry of MNCs and globalization } \\
\text { - } \quad \text { Arrival of new companies } \\
\text { - } \quad \text { Decreasing attachment of entrepreneurs to } \\
\quad \text { a specific area } \\
\text { - } \quad \text { Buyers and sellers treated impersonally } \\
\text { - } \quad \text { Poor infrastructure }\end{array}$ \\
\hline $\begin{array}{l}\text { Cooperation } \\
\text { - } \quad \text { Interdependencies } \\
\text { - } \quad \text { Reciprocity (reciprocal gifts) and sharing of } \\
\text { production } \\
\text { - } \quad \text { Long-term personal relations } \\
-\quad \text { Coordination through mutual adjustment }\end{array}$ & $\begin{array}{ll}\text { Competition } \\
\text { - } & \text { Market-based and calculative relations } \\
\text { - } & \text { Contracts and commercial reasoning } \\
\text { - } & \text { Opportunistic behaviour } \\
\text { - } & \text { Negotiating power } \\
- & \text { Free-rider attitude } \\
\end{array}$ \\
\hline
\end{tabular}

The literature contains different and conflicting visions. The canonical studies insist on the resolutely cooperative nature of the industrial district and the embeddedness of economic transactions within the framework of social relations, while recent studies, more concerned with transformation analysis, tend to insist on the importance of competition and disembeddedness with 
fewer local inter-firm relationships, less inter-organizational learning and the disappearance of local institutions. In this view, convergence toward a unique model based on market relations is inevitable as internationalization develops.

But we argue that it is a rather deterministic view of the industrial district. This paper deals with modern adjustments being made by districts in relation to external pressures. How do the pressures of globalization and disembedding work to reconfigure inter-firm relations in such a district? Is there a "normal" trend toward disembeddedness and disappearance of older systems? The purpose of this study is to analyse the processes and consequences of disembedding and internationalisation for the changing shape of inter-firm relations, the transformation of subcontracting and the evolving role of institutions.

\section{The data collection and interpretation process}

The case study method was selected (Yin, 1989). This thick description allows an understanding of the evolution of industrial districts at more than a superficial level. We therefore performed a retrospective study using a number of different data sources based on anecdotes provided by members of each organisation and personal accounts of real-life situations or critical incidents, archives, documents and elements reconstituted after the fact.

We chose this method largely through the desire to approach the district from a purely macroeconomic angle, giving an interpretational viewpoint that incorporates the ways in which the various actors have experienced, interpreted and performed actions during these different periods.

Our objective was to select the district considered by various authors as most similar to the classical model of the industrial district. We decided on Technic Valley (also called the Arve Valley) since it is considered the most significant French district in a number of studies (Ganne, 1991; Courlet and Leger, 1998, Reverdy, 2001).

Initially, we used the survey of Technic Valley conducted since the 1980s by IRTE (Institute of Research on the Economic Fabric and Employment - Institut de Recherche des Tissus Economiques 
et de l'Emploi). This data comprised detailed reports from round tables on development of the district and its key problems, and the documentary archives built up about the district over the last 20 years. A series of 20 interviews was also conducted between 1998 and 2001. This study describes the functional organisation of Technic Valley as well as relationships between the various actors. The interviewees were members of the main organisations within the industrial district of the Arve Valley, such as the local development unit, key businesses within the district and public bodies and training organisations.

Subsequently, we performed a further series of some ten interviews (2001-2003) among the institutional bodies located in Technic Valley such as the Technical Center for Bar Turning (CTDEC), the National Syndicate of Bar Turning (SNDEC) and the Strategic Observatory of SubContracting (OSST). These interviews were conducted with the presidents of the institutions in question. In addition, using the directory of subcontractors implanted in the region, we consulted a number of company directors present in the Arve Valley (20 interviews). We carried out some ten interviews with key players within the district following submission of an application for the label of 'competitiveness cluster', obtained in 2005 (see table 2).

TABLE 2. DATA SOURCES AND PROCESSING FOR EACH PHASE

\begin{tabular}{|c|l|l|}
\hline Phase & \multicolumn{1}{|c|}{ Collection } & \multicolumn{1}{c|}{ Processing } \\
\hline $\begin{array}{c}\text { 1729- 1960 } \\
\text { (P1 and P2) }\end{array}$ & $\begin{array}{l}\text { Secondary data (archives, historical works) } \\
\text { submitted by IRTE }\end{array}$ & Reconstitution of history of the district \\
\hline $\begin{array}{c}\text { 1960-1989 (P } \\
\text { 3 and P4) }\end{array}$ & $\begin{array}{l}\text { Secondary data (archives, historical works) } \\
\text { submitted by IRTE }\end{array}$ & $\begin{array}{l}\text { Thematic analysis based upon analytical } \\
\text { reading tool and retrospective accounts by } \\
\text { actors }\end{array}$ \\
\hline $\begin{array}{c}\text { 1990-1996 } \\
(\text { P5) }\end{array}$ & $\begin{array}{l}\text { Secondary data and reports of IRTE notebooks for } \\
\text { the period + analysis of studies conducted on the } \\
\text { district (Puthod, 1995) }\end{array}$ & $\begin{array}{l}\text { Thematic analysis of secondary data and IRTE } \\
\text { notebooks } \\
\text { Statistical data from Puthod study (1995) }\end{array}$ \\
\hline $\begin{array}{c}\text { 1997-2003 } \\
\text { (P6) }\end{array}$ & $\begin{array}{l}\text { 20 IRTE interviews } \\
\text { 30 interviews conducted by researchers in 20 } \\
\text { SMBs and 10 institutions }\end{array}$ & Thematic analysis of the 2 series of interviews \\
\hline $\begin{array}{c}\text { 2004-2006 } \\
\text { (P7) }\end{array}$ & 12 interviews + cluster of competitiveness dossier & $\begin{array}{l}\text { Analysis of the 'cluster of competitiveness' } \\
\text { dossier + thematic analysis of interviews }\end{array}$ \\
\hline
\end{tabular}

Finally, a thematic analysis was performed on all qualitative and secondary data. All interviews 
were retranscribed in full and were then coded using a dual coding procedure. Secondary data were also analysed using this same procedure. A majority of themes and codes were determined in advance in accordance with our analysis of the literature (Markusen, 2003) (see table 1), while others emerged progressively as data were collated

\section{Process-based analysis of an industrial district in France : Context, nature of relations and evolution}

The Technic Valley (Arve Valley) industrial district contains a very dense concentration of companies. More precisely, it consists of a network of 550 small and medium-sized businesses (SMBs) and industries working within the bar-turning sector. Bar turning is defined as the most competitive process for the production of medium-sized and large series of parts, generally mechanical, using plans or models for which the raw parts are obtained from bars or blanks using automatic or semi-automatic machines. The pieces of metal in this activity are very small and are used for example in the aviation industry or the automobile and electrical industries to manufacture precision mechanisms such as meters, alternators or clocks,

This district is responsible for $65 \%$ of bar turning in France (with half of its output going to the automobile industry) and has an annual sales turnover of 763 millions of euros, with extensive export activities. Three-quarters of the companies export their products and these sales represent one third of the district's revenue. This district contains the highest concentration of bar-turning companies in the world. Technic Valley, located within a radius of some 30 kilometres around the town of Cluses, is thus of crucial importance for the region, since it provides direct employment for 13000 people out of a total population of 60000 (see Figure 1). The bar-turning industry thus accounts for some $82 \%$ of companies and $70 \%$ of industrial workers within the district, making it the most important industrial district in France (see table 3).

The Arve Valley is also home to a considerable number of support businesses such as research consultancies and methodology consultancies, which are accessible to all companies in the valley at 
reduced costs. Bar turning also generates associated activities both upstream and downstream of the principal activity providing privileged access to the various supply circuits.

TABLE 3. ECONOMIC CHARACTERISTICS OF THE TECHNIC VALLEY

\begin{tabular}{|l|l|}
\hline & Technic Valley District \\
\hline 1. Number of small- and middle-sized companies & 550 companies \\
\hline 2. Staff size of companies & $75 \%<20$ employees: $88 \%<50$ employees \\
\hline 3. Sales/domestic market & $65 \%$ of French production \\
\hline 4. \% Local employment within district & $20 \%(13000$ people $)$ \\
\hline 5. Company structure & Mainly fly businesses \\
\hline 6. Sector & $\begin{array}{l}\text { Traditional - Bar turning; } 250 \text { 000 metric } \\
\text { tonnes of metal transformed annually }\end{array}$ \\
\hline
\end{tabular}

\section{A 40 LYON-GENEVE (motorway)}

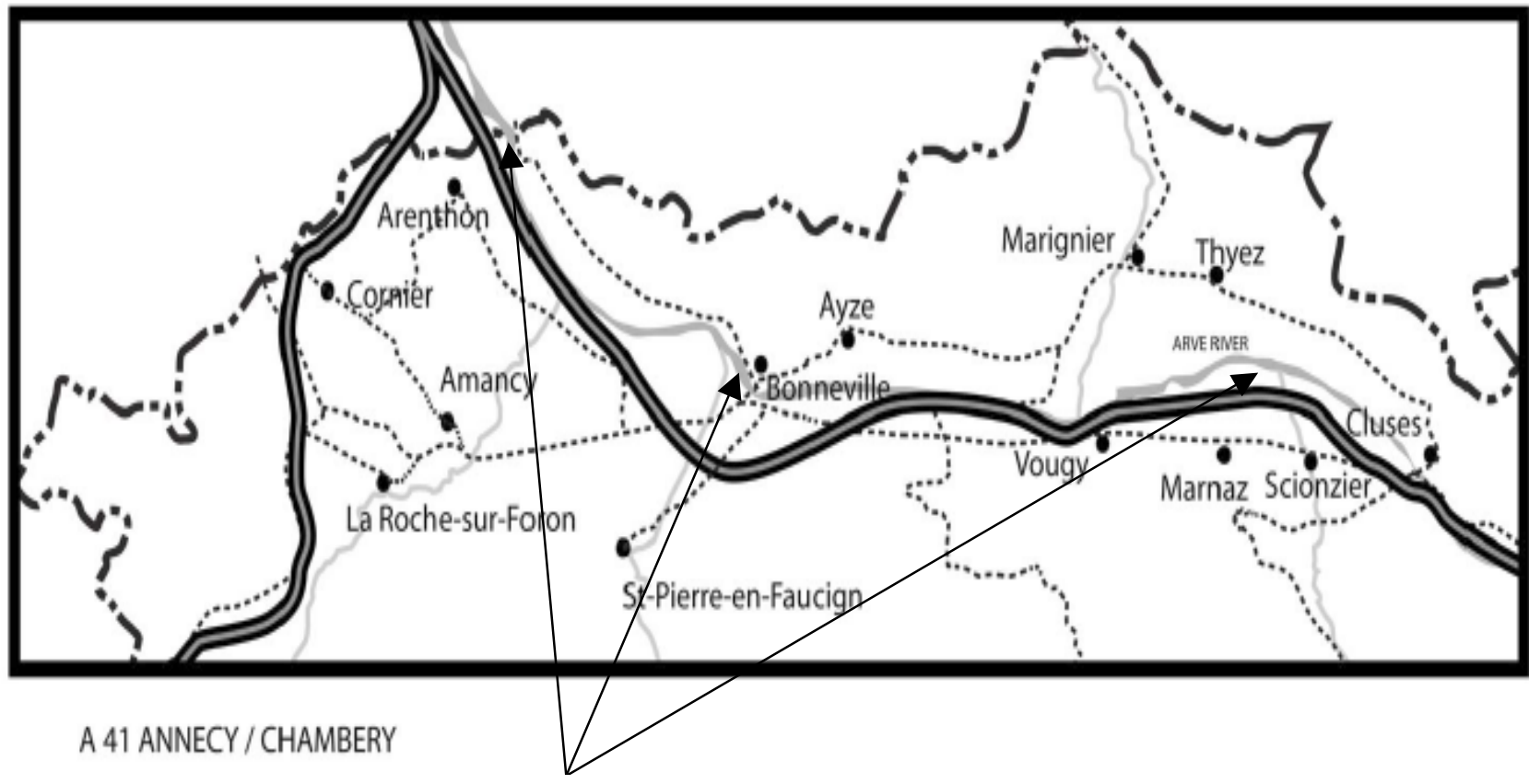

ARVE RIVER

A valley surrounded by mountains and crossing by the Arve river

\section{FIGURE 1. MAP OF THE TECHNIC VALLEY}

The overall attractiveness of Haute-Savoie is an extremely important factor, and the territorial position is especially significant. The Arve Valley is a mountainous agricultural area, with industrial traditions, that lies close to Switzerland and Italy at the foot of Mont Blanc known primarily for its industrial background. Because it is near two international airports, as well as a regional airport, the valley is less than two hours from all major European cities. In addition, the 
'Autoroute Blanche', which passes through the Mont-Blanc tunnel, provides a rapid link with Italy and Eastern Europe. Again, Cluses is on the TGV line. Thus, the Arve Valley fits conveniently into the French and European transport networks.

\section{Overview of the history of the district and new challenges}

During the $17^{\text {th }}$ century, the activity of the valley's population was principally agricultural. However, faced with marked demographic growth, an increasing number of inhabitants were forced to leave the area due to the lack of adequate agricultural resources. The building of the industrial district owes its origin to one of these expatriates, Claude Ballaloud, who left in 1719 for Nuremberg in Germany, where he entered the clockmaking business before choosing to return to his native region. On returning to Cluses in 1720 , he decided to recreate what he had seen abroad and introduced clock-making techniques to Haute-Savoie. In his workshop, he trained many journeymen who subsequently left and moved out into the adjoining communes to create their own businesses.

Throughout the $19^{\text {th }}$ century, the valley specialised in the manufacture of wheels and gears used in clockmaking. The industry reached its zenith between 1860 and 1890, accounting for some $70 \%$ of the world's production. In 1873, César Vuarchex, who learned the trade of bar turning in Paris, set up the first bar-turning workshop. At the end of the $19^{\text {th }}$ century, the clockmaking industry went through a period of crisis, and the inhabitants of the valley were forced to find new markets. After a period of subcontracting on an individual basis, the activities in the valley gradually became mechanized and industrialized during the $20^{\text {th }}$ century. The First World War marked a decisive turning point for local industry since the munitions industry necessitated reconversion of the clockmaking industry to production of larger items, thereby prompting the development of bar turning.

The munitions industry, developed to bolster the French national war effort, allowed the district to industrialise its production processes through the medium- and large-scale manufacture of standardised metal parts. After the First World War, this enabled producers in the valley to 
gradually turn towards other markets, in particular the automobile, aviation and telephone industries, which required the production of numerous mechanical parts.

During the 1950s, Technic Valley worked primarily for the automobile industry, with its chief activity being that of specialized subcontracting in bar turning. The 1960s represents the golden age of bar turning in the Arve Valley. This period is characterized by the arrival of contactors inside the district attracted by the image of the district and proximity of sub-contractors. Then, since that time, we can observe the coexistence of contractors located inside and outside the district. In 1974, like all industrial districts, the Arve Valley district was affected by shock waves from the oil crises. Automobile manufacturers reacted to this new economic environment by imposing new quality standards and new production methods. The oil crises in fact proved a catalyst for profound changes in the production system, which was forced to adjust to a triple mutation: a) transfer of pressure from customers to subcontractors: pressure in terms of production costs, quality (zero defect) and delivery times (zero stock), with the introduction of the just-in-time system; b) introduction of new materials and use of new competitive bar-turning technologies; c) renewal of machinery.

The structure of the industrial fabric, in which SMBs continued to prevail, moved towards concentration with the creation of regional and national groups. These changes resulted in differential growth among companies in the valley.

Finally, growth of the district associated with adaptation to the automobile industry generated two types of effect: the introduction of management standards requiring reorganization of the actors and creation of shared support institutions; and the arrival of clients within the district and implantation of service providers attracted by the success and organisation of the district.

Since 1990, the industrial district has been faced with a new global universe. The 1990s and the present decade are characterized by a phase of acquisition and mergers of the key companies in the profession organized by two types of actors such as major banks, particularly foreign banks and foreign groups, principally Italian, American and German groups (see text box 1). Companies taken over were chosen on the basis of the quality of their workforce and their levels of R\&D investment, but above all because of their outstanding geographical situation, with some being selected as 
logistics bases for intercontinental activities: "The key companies within the profession have been sold because of family inheritance problems. 25\% of the Valley's turnover has passed out of the hands of traditional family companies." (President of Local Institution A).

\section{Text box 1. Reasons cited for company takeovers by foreign groups and their consequences}

The reasons for company takeovers cited by businesses in the valley are of two types:

problems of company handover (finding a taker within the family or within the company, tax problems associated with company handover, etc),

handover is associated with a lack of clear landmarks for company management and an environment considered increasingly competitive and difficult.

In 2005 , foreign companies held stakes in $27.2 \%$ of subcontracting companies in the Haut-Savoie region employing more than 50 staff. Only the largest companies (more than 100) were purchased outright. These takeovers are related to worldwide developments in terms of restructuring of the value creation chain. Foreign purchasers have four major aims in setting up in the Arve valley:

they seek to benefit from the quality image associated with leading companies in Technic Valley,

they require fast returns on their investment (a financial consideration, particularly for investment funds and foreign venture capital),

the idea is to offer a wide product range and strengthen their geographical and technological position (proposal of additional technologies) in order to improve their offer to customers,

economies of scale can be enjoyed in terms of support businesses (mergers between companies in the same sector).

Since 2000, the district has been characterised by delocalisation (in the quest for cheaper labour) and increasing competition from the emerging countries (see text box 2). The acceleration in changes to the environment means that delocalisation often has to be embraced at break-neck speed.

\section{Text box 2. Factors accounting for delocalisation in the Arve valley}

In the Arve valley, delocalisation is associated primarily with two strategic approaches that go hand-in-hand: defensive delocalisation comprising set-up in countries with low wage structures in order to remain competitive. Delocalisation is chiefly towards three geographical zones: 1) Eastern Europe (mainly the Czech Republic, Slovenia and Hungary), 2) South America (mainly Brazil), and 3) Asia (mainly China and India).

"In order to maintain the French sites, we have had to delocalise all assembly operations to countries with low wage costs." (President of SBE 15)

"The movement is unstoppable; a worker costs 1 euro (gross hourly wage) in China, 4.5 euros in the Czech Republic and 14 euros en France." (President of SBE 19)

- delocalisation of accompanying businesses, which may be defined as a cascade of suppliers following their main customers in their international development.

For instance, Bontaz Centre employees 300 staff in France, 300 staff in the Czech Republic, 300 staff in China and 100 staff in Brazil.

"When several major customers such as Fiat, GE or Renault tell us "You must delocalise to India," we either follow their instructions or risk losing our contracts in France in the mid-term." (President of SBE 20)

"If we don't go international, we just won't be in the market for new tenders. We really have no choice." President of SBE 3)

However, for the moment delocalisation primarily concerns low-tech labour-intensive activities such as assembly, control and logistics. In contrast, design, engineering and manufacturing activities, which require innovation and advanced technical skill, remain for the time being in the Arve valley.

"Today, it is the quality of technical innovation that allows us to hold out in the short term, while hoping that the other countries do not progress too rapidly on this front." (President of SE 22) 
We shall examine how recent changes, especially under pressures of internationalization, have worked to reconfigure inter-firm relations in such a district. A graphic representation of the district in the contemporary period is shown as Figure 2. This figure allows us to observe how actors are organized nowadays in the district in response to the transformation of their environment. The Technic Valley appears to be a very complex system with the coexistence of relations of cooperation and competition between firms within the district and different forms of relations between local firms on one hand, and local, regional and national institutions, internal and external contractors and suppliers on the other hand.

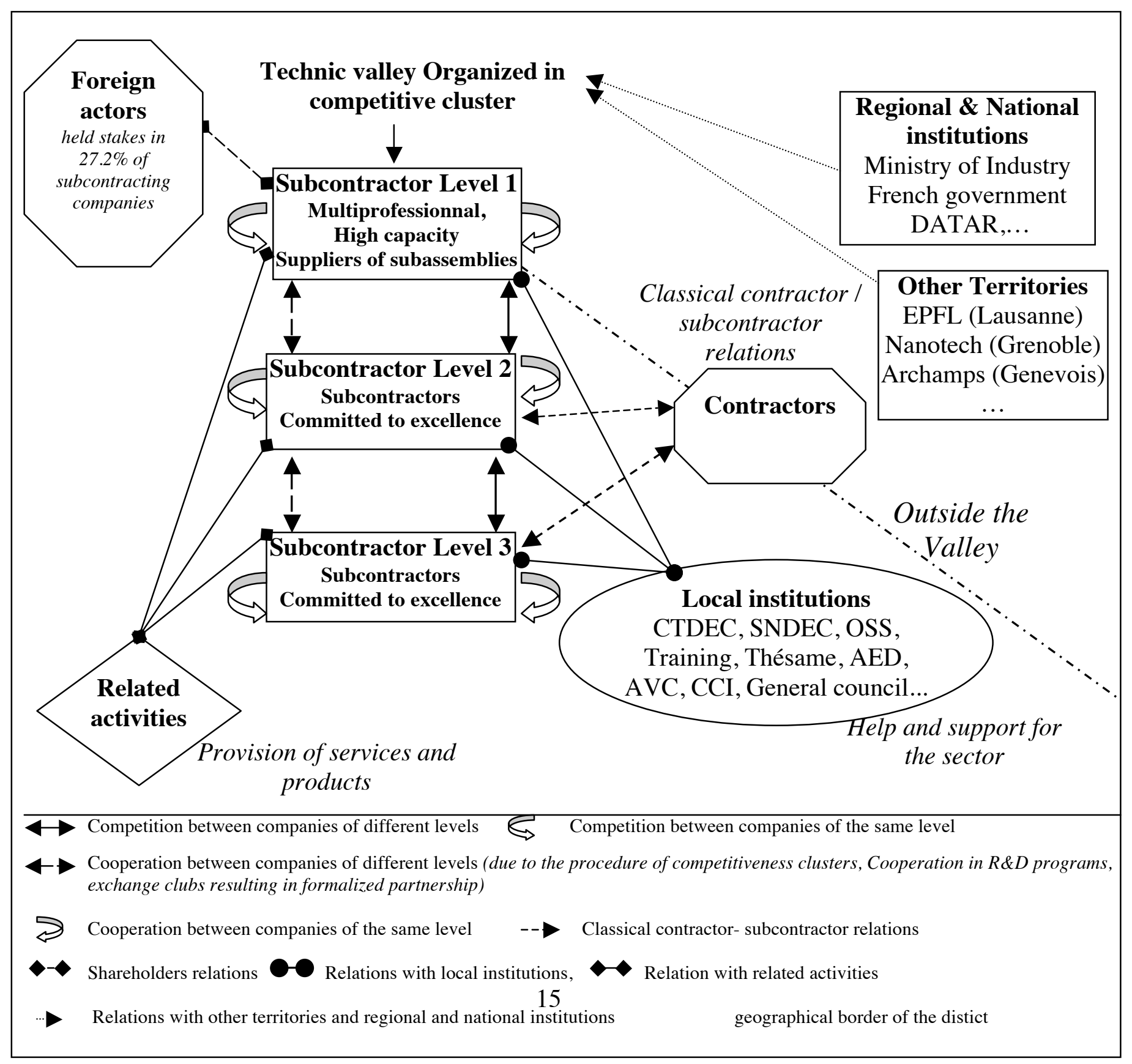




\section{FIGURE 3. GRAPHIC REPRESENTATION OF THE TECHNIC VALLEY IN 2006}

We examine these changes by means of three types of analysis presented below in succession:

- The changing nature of subcontracting and 'trade' interdependencies, and more precisely relations between firms within the district and their clients;

- The changing shape and form of inter-firm trust, contract and network forms in the district, i.e relations between firms within the district;

- The changing role of institutional infrastructures and 'untraded' interdependencies, i.e relations between firms within the district and local institutions.

\section{Changing relations between companies in the district and their clients : A contract-based}

\section{approach}

At the start of the 1990s, the industrial district could be broken down into three groups:

- Level-one subcontractors or "jewels in the crown". Their mean size is superior to one hundred employees. They are specialized in a particular sector of activity (automobiles, aeronautics, etc.) and they work directly with contractors.

- Level-two subcontractors who enjoy privileged relationships with a level-one subcontractor or who have a diversified portfolio of activities in various sectors allowing them to maintain direct contact with certain customers. In general, the local company uppermost in the hierarchy shares the spoils of a healthy market with these companies, which are often managed by family members or friends.

- Level-three subcontractors, who in some cases work at home on finishing goods and who take up surplus activity.

However, this breakdown does not give an adequate idea of the complexity of the region. Bar turners may in fact be alternatively level 1, 2 or 3 subcontractors depending on customers or even on the size of orders received from a single customer. The district may in fact be considered a region with a dense population of bar-turning companies able to adapt and modify their competitive 
strategy extremely rapidly according to circumstances.

Relations between firms and their clients are mainly informal where they involve subcontractors and their internal customers (i.e. within the district) but relatively formal where they concern outside clients.

From 1990 onwards, under pressure from manufacturers, subcontracting became more specialised and selection criteria tended towards more organisational aspects while specifications became more functional. Extension of the modularisation concept led to a drastic reduction in the number of direct suppliers who were involved with everything from design to production of modules for which they were responsible, as well as generalisation of risk sharing. The manufacturers withdrew from detailed design work and attempted to reduce concentration of efforts in this type of activity inhouse. The SMBs emphasise the highly selective nature of the effect of generalised recourse to outside service providers on the part of automobile companies, which involves participation of the major service providers in the risks inherent to all R\&D operations. In addition, these companies were under enormous price pressure.

Many companies were in difficulty and the turnover of the district fell, accounting for competition from other materials, shortage of qualified labour within the district, strong downward pressure on prices and the difficulties encountered by company heads on passing over the reins.

In addition, the initial structural organisation of the district (level 1, 2 or 3 subcontractors) is now tending towards differentiation between subcontractors based upon their development strategies. In this respect, four types of subcontractors may now be distinguished within the Arve Valley:

- Subcontractors with a high capacity (generally level 1) deploying a high-volume strategy. These companies are under the greatest threat since they are highly sensitive to the "low-cost" countries.

- Subcontractors committed to excellence (generally levels 2 or 3), whose strategies are based upon continuous improvement of methods and who are able to offer high-quality products at low cost while remaining flexible in terms of lead times. 
- Suppliers of subassemblies (generally level 1) employing a number of different technologies and tending towards the production and/or assembly of complex systems. They oversee a chain of subcontractors and are closely involved in the supply chain.

- Multi-professional companies (generally level 1); these are medium-sized ultra-specialist firms (with up to a few thousand employees) with a high-level production system and, in addition to design offices, have a veritable R\&D department involved in advanced product design working jointly with customers.

This change is also accompanied by strengthening of the contractual bonds between automobile constructors (or clients in other sectors) through the introduction of many quality procedures and the performance of numerous audits designed to improve the efficacy of inter-company relations: "Today we have practically no room left for manoeuvre. Existing quality procedures mean that we hold no secrets for our customers" (President of SBE 13). We can see a change towards greater formality in relationships between contractors and the various companies within the district: "Orders are increasingly detailed and precisely drafted" (President of SBE 8). The practices and behaviour of contractors have also changed significantly, in terms of time management, work organisation, performance and production management.

Further, a trend may also be seen among client customers towards an increase in strategies favouring the economic dimension (cost / profitability) to the detriment of the traditional criteria of trust and social or geographical proximity. Contractors have no hesitation in placing each new contract with their subcontractors in the balance and ultimately selecting suppliers purely on economic grounds. For instance, as one director puts it: "At the start of the 1990s, a simple hand shake would be enough to secure work with a contractor for years on end. Nowadays, contracts are formally written out and relations are short-term and based mainly on the price of the service. This is fairly unhealthy. The profession is suffering overall, with very low profit margins.” (President of SMB 25).

Table 4 is a synthesis of the evolution of the client-subcontractor relations from 1990 to 2006. 
Table 4. Client-subcontractor relations in 1990 and 2006

\begin{tabular}{|l|l|l|}
\hline Structure of the district & T1 (before 1990) & T2 (2006) \\
\hline Subcontractors Level 1,2 and & $\begin{array}{l}\text { Subcontractors with high } \\
\text { capacity, committed to } \\
\text { excellence, suppliers of } \\
\text { subassemblies, multi- } \\
\text { professional companies }\end{array}$ \\
\hline Strategies of customer firms & Informal with internal clients & $\begin{array}{l}\text { Highly formalized } \\
\text { Contract-based approach to } \\
\text { business }\end{array}$ \\
\hline $\begin{array}{l}\text { Choice of subcontractors based } \\
\text { on a mixture of proximity, } \\
\text { product quality and rapidity }\end{array}$ & $\begin{array}{l}\text { - Delocalisation of products } \\
\text { with low added value } \\
\text { - Highly technical products } \\
\text { involving quality of service } \\
\text { kept within the district }\end{array}$ \\
\hline
\end{tabular}

\section{Changes in relations between companies within the district: Strengthening of formal cooperation}

Until the 1990s and if we consider firstly subcontractors, relations between them were characterised chiefly by intense competition: "On a continuum, we could say that the district comprised $80 \%$ competition and $20 \%$ cooperation." (President of SMB 8). This fierce competitive climate is in fact considered by the key actors as having constituted the main driving force of Technic Valley and the principal reason for its success in the past : "Competition was strong because of contractors who turned the screw to force prices down. Moreover, proximity encouraged emulation. If we saw a competitor had a new machine we asked ourselves why we hadn't got one." (President of SMB 14). The principle of winning markets from one's neighbours resulted in emulation, allowing the Arve Valley to create lasting competitive advantage in terms of innovation and adaptability. However, at the same time, lines of cooperation and solidarity existed between certain actors; principally between companies specializing in different segments of the chain of activity or members of the same family. According to one SMB director: "My parents always said that you should never hesitate to take a contract from under a neighbour's nose, but it's important to help each other when serious problems occur." (President of SMB 8)

Relationships between the actors were chiefly informal and based upon the sharing of a common culture marked by the importance of entrepreneurial values, pride in work well done and a particularly willing disposition. In addition all the directors of subcontracting companies were very closely attached to their region ("Our family is very attached to the Arve valley, traditions and to the defence of the region. Because we are here for 
generations, we all know each other and we have a common culture and we have made a success of things through sheer hard work.": President of SMB 24) and to the activity of bar turning.

At this time, alliances between companies were relatively rare and in any case ad hoc: "People enjoyed getting together for a chat and for meals, but in business, it's a question of devil take the hindmost." (President of SMB 2). They were generally created during the course of responses to important calls for tender in order to allow smaller companies to compete with larger businesses. Recourse to outside companies was generally dependent on circumstance, as exemplified by sharing of work during times of high demand. It was more a question of several companies seizing opportunities rather than deliberately working out a veritable common strategy. Ad hoc cooperation was undertaken above all on an informal basis. For instance, a subcontractor might agree to manufacture 2000 parts for another company within 48 hours simply based on a verbal agreement. As a result of trust between the actors involved (geographical proximity, shared values, family business, historical presence in the region), the work was done without the need for a written contract, except for sizeable orders that could expose companies to extensive risk:

Opportunistic behaviour was nevertheless quite rare, since the consequences for the reputation of the entrepreneur concerned were immediate and heavy, resulting in boycott: "Business was conducted by word of mouth and we gave work to one another. We wouldn't have thought twice about pinching a contract." (President of SMB 1)

The strength of the district appeared to reside in the presence within the same region of all the companies necessary for the activity of bar turning. This geographical proximity between the various actors within the sector allowed the companies to be flexible (over $40 \%$ of purchases are procured locally), supple and reactive while maintaining their edge in terms of innovation: "Our key strength is our involvement in a profession where everything we need is at hand. For instance, we have stores of starting materials nearby and we can take delivery within an hour of ordering. Technic Valley is a system where all the actors are present and interact with one another." (President of SMB 19). In fact, one of the main advantages of the district "is the immediate availability of commodities, which greatly helps the performance of companies. Being able to order metal bars and tools almost continually without the need to store items, or to finance maintenance departments within companies thanks to the existence of highperformance external businesses, having the CTDEC just around the corner and having major customers and partners just along the road ... all of these things contribute to the informal network of the region." (President of SMB 5). 
However, the mergers and acquisitions carried out by foreign banks, troubled with the localisation strategies by customer companies and increased international competition, have impacted to various degrees on companies within the district. On the one hand, these changes to the environment have raised fears of loss of know-how prompting certain actors to cooperate less readily. According to one company director: Today, the major bar-turning companies belong to bankers or foreign groups. We're afraid of giving away the expertise accumulated in the valley, which can then be learned and taken elsewhere." (President of SMB 3). These strategies are based in part on what is perceived as a local loss of power: "Management styles have changed in the wake of mergers. The decision-making centres are no longer situated in the valley." (Member of Local Institution E).

On the other hand, these changes have also produced partnerships between the different actors. A policy of cooperation was also promoted by the local institutions that militated to make the various actors aware of the usefulness of developing closer collaboration and concentrating on the manufacture of more sophisticated goods in order to successfully face foreign competition. The small and mid-size businesses and industries were encouraged to coordinate their strengths in order to be able to carry out the complete range of additional activities connected with bar turning. Co-operation was viewed as a necessary condition of survival within the district: "Today, our competitors are abroad. We recommend cooperation between the different actors within the valley, in order to increase their strength in unity. We have to find ways of sharing, ways of achieving mutual strength." (President of SMB 9). This allowed them to react more quickly and provided them with a means of developing complex assemblies or subassemblies that formerly could only be manufactured by large companies: "The District will survive. The heirs to the family groups have been trained and have lived in the valley for many years. They know how to turn their hand to factory work. Our expertise will survive." (President of institution F). A number of partnerships were thus formed in order to better coordinate the individual efforts of each company. For instance in 1998, INTERDEC, an industrial group comprising eleven companies, was born. This conglomerate acts as a purchasing group for metals and carries out commercial prospecting in France and abroad for member companies. Thus, the members of the district have undertaken collective actions between companies in order to preserve the region's competitive edge: “There has been a total turnaround in attitudes. A few years ago, we were all 
competing against one another, but now I find myself working hand in hand with competitors in order to win major contracts jointly."(President of SMB 32).

Finally, the shared culture of entrepreneurs has been affirmed: "Bar turners are united by the same work culture and technical development. They have a taste for innovation. They are consistently striving to work better and faster. They're always on the lookout for ways of better meeting their customers' needs." (Member of local institution C). These values have been advanced to initiate new and more profound forms of co-operation.

The different attitudes of subcontractors indicate trends towards both disembeddedness such as the withdrawal of certain actors, delocalisation, sell-out of companies to foreign groups. They also indicate trends towards embeddedness such as reduction of internal competition, creation of formal partnerships and increased co-operation. (see table 5)

The tendency towards co-operation is strengthened by local institutions, particularly as regards the project to achieve competitiveness cluster status.

Table 5. Relations between subcontractors in 1990 and 2006

\begin{tabular}{|l|l|l|}
\hline & T1 (before 1990) & T2 (2006) \\
\hline Type of relations & $\begin{array}{l}\text { Predominance of competitive } \\
\text { behaviour between companies } \\
\text { with limited forms of } \\
\text { cooperation involving non- } \\
\text { strategic affairs }\end{array}$ & $\begin{array}{l}\text { Withdrawal or moving of } \\
\text { certain actors }\end{array}$ \\
\cline { 3 - 3 } & $\begin{array}{l}\text { Strengthening of formal } \\
\text { cooperation on strategic affairs }\end{array}$ \\
\hline
\end{tabular}

Changes in relations between companies in the district and institutions: an increasing institutionalisation

Prior to 1990, many institutions already existed within the industrial district, in particular the Royal School of Clock-Making, training institute founded in 1848, the SNDEC (Professional Syndicate of Bar Turning, founded in the mid- $20^{\text {th }}$ century) and the CTDEC (Technical Centre for Bar Turning, created in 1962 to provide the district with a joint R\&D institute). The purpose of these institutions was to provide bar turners with the support needed for their development. However, practically all committed actions have been undertaken at the prompting of entrepreneurs. For example, Guy 
Firmin was responsible for the creation of the Royal School of Clock-Making while Roger Frank oversaw the creation of the CTDEC. They solicited political and professional bodies whose role was to find solutions tailored to their needs. Before 1990, these local institutions were thus not instrumental to change within the industrial district but rather played a passive supporting role in such change in accordance with the needs of local actors.

From 1990, two types of change were particularly evident and we shall examine them in succession. The first one is the increase in the number of institutions created. There is a strengthening of the institutional network around companies in the district.

The first institution to be created was Thésame (the European Centre for Business and Innovation) in 1990. The idea was to create a body focused on innovation and specialized in new professional areas such as mechatronics, industrial organisation and management of innovation. Thésame comprises a network of multidisciplinary experts mainly from the region's universities and local research centres, and to which companies in the industrial district can turn for help with their projects. In particular, the centre offers business monitoring tools, organisation of industrial meetings, market opportunity studies and project engineering.

1993 saw the creation of a new institution within the district, the Departmental Economic Agency (AED), whose function is to develop and preside over economic services in the region. In particular, the goals of the AED are to help with access to new information and communication technologies, to promote the industrial fabric, to initiate and support development projects and to promote cross-frontier collaboration with Switzerland.

In 1995, the region also created a third institution: an association for the promotion of skills in order to help unaccompanied businesses within Technic Valley in fields as varied as provisional areas and skills management, training, promotion of individual professional skills and human resource diagnosis. Moreover in 1997, under the impetus of regional manufacturers, a Strategic Observatory of Sub-Contracting (OSS) was created, one of whose roles is to set up clubs for exchange and reflection within the various sectors (automobile industry, connectics, medical, luxury goods, 
aeronautics) and whose membership comprises some 40 companies. This observatory also provides a strategic monitoring service for all companies within the valley in the form of a monthly news letter and organises meetings on different topics with guest participants from outside the region.

In addition, the local institutions favour the development of specialized training institutes in the region in order to provide qualified labour and also set up long-term training programs. For example, a professional degree in industrial production with specialisation in digital bar turning was created in 2002 with the support of SNDEC: "From 1989 to 1998, 800 staff were trained using qualification contracts. Now between 2001 and 2011, we have a project to train 1300 employees on qualification contracts. France is the only country to have a specific training programme for bar turning. We are the only ones to recognise this profession as a specific activity." (Member of local institution $G)$

The second evolution is a change in the role of institutions from passive to active. They take now initiatives to enable the district to adapt to the changing environment. In this respect, the industrial district decided more recently to seize an institutional opportunity at the national level in order to increase its competitiveness.

On 2002, the French government adopted a new industrial policy aimed at an improved synthesis of regions, innovation and industry. The newly created "competitiveness clusters" are aimed at developing industrial activities and job opportunities and at strengthening the regions. This policy took form with the launch on 14 September 2004 of a call from the Interministerial Committee for Regional Organisation and Development (CIADT) for applications from the regions for this new status. In order to be granted this status, candidate regions were required to possess a high-level combination of the three key ingredients (companies, training centres, research units) and three decisive factors (partnerships in particular between the public and private sectors, R\&D projects and an international profile).

Thanks to its history and inherent advantages, Technic Valley staked its claim to become a competitiveness cluster ${ }^{3}$, submitting a project in February 2005. The application is supported by a

\footnotetext{
${ }^{3}$ This section is based largely on competitiveness cluster project files submitted to the government before 28 February 2005 . The quotations in italics are taken from such dossiers and from semi-directive interviews with the players, as in the previous phases.
} 
federation comprising all the local partners. The aim is to create an industrial project together, in particular with an important strategic dimension and fundamental emphasis on innovation. This will allow transition of companies initially focused on bar turning towards the design of complex assemblies and subassemblies involving multiple technologies and the professional expertise of mechatronics. The aim is two-fold. First, the project will attempt to capitalise on the existing structure and preserve the present system while improving coordination of the district and the steering bodies: "The region and the companies within the valley are now at a crossroads. We are facing increasing problems from the low-cost countries and Asian competitors, despite the fact that the valley has always been the leader in this field and at the cutting edge of technology. It is essential for our companies to continue to innovate in terms of technologies, manufacturing processes, productivity and quality, in order to maintain our position as leader. The creation of a competitiveness cluster offers an exceptional opportunity to fuse the energies of the district together around this development project." (President of Association A, extract from the competitiveness cluster project file)

Second, the district now has a new method of strategic surveillance allowing better anticipation of changes in its environment in the future, and even initiation of such change.

In order to achieve this, the district is pinning its hopes particularly on the transfer of innovation, which is becoming an increasingly vital issue for Technic Valley. For example, this turns on grouping training establishments together: "We are seeking to unite the forces of the EIPM (European Institute of Purchasing Management), those of Grenoble EM and those of the Irège Research Centre and the University of Savoie, to create a platform able to raise awareness among companies and train them in purchasing issues and practice, and to undertake research into how purchasing patterns can improve the competitiveness of small and medium-sized companies" (extract from the competitiveness cluster application dossier).

This new phase in the development of the district was accompanied by the creation in early 2005 of a new institution, the Arve Industry Association, whose mission is "to systematically implement the aims and programs of the new competitiveness cluster." In particular, the goal of the association is "to guarantee the development of the valley through the creation of an 'economic management council for the Valley' and to encourage the development of research and innovation for the benefit of the district's companies." 
The aim of the competitiveness cluster project is thus to lend coherence to the actions conducted by all of the local institutions present in the region by coordinating research, training, managerial innovation and funding policies, and by encouraging co-operative projects.

The idea is to endow the region with a number of specialised institutions dealing with different topics in order to help companies within the district develop (see Table 6).

Table 6. Local institutions at the service of the district

\begin{tabular}{|l|l|l|l|}
\hline $\begin{array}{c}\text { Commercial } \\
\text { partners }\end{array}$ & Financial partners & Technical partners & \multicolumn{1}{|c|}{ Training partners } \\
\hline $\begin{array}{l}\text { Expansion } \\
\text { committee }\end{array}$ & European Union & CTDEC & Universities and Professional \\
AED & Legional Councils & Thésame & Schools. \\
& Gecal Town Halls & OSST & \\
& Genel Council the agglomeration & 23 university research & \\
& centres & \\
& French Banking & & \\
\hline
\end{tabular}

Thus during this phase, as summarised in Table 7, in response to the violent environmental shocks, the players involved are striving to reorganise the district, particularly through the creation of institutions with an increasingly active role that encourage subcontractors to develop more systematic and formal types of co-operation and increase experience sharing.

Table 7. Relations between subcontractors and local institutions in 1990 and 2006

\begin{tabular}{|l|l|l|}
\hline Role of institutions & \multicolumn{1}{|c|}{ T1 (before 1990) } & \multicolumn{1}{c|}{ T2 (2006) } \\
& $\begin{array}{l}\text { Passive role: creation of } \\
\text { institutions in accordance with } \\
\text { the needs of and requests by } \\
\text { entrepreneurs in order to allow } \\
\text { adaptation to the environment }\end{array}$ & $\begin{array}{l}\text { Active role: encouragement of } \\
\text { small and medium-sized } \\
\text { businesses to draw up formal } \\
\text { contractual relations and } \\
\text { strengthen levels of innovative } \\
\text { co-operation to fend off outside } \\
\text { competition }\end{array}$ \\
\hline
\end{tabular}

\section{Discussion and conclusion}

As Boschma and Lambooy (2002: 303) stress, there is no reason to believe that industrial districts will follow a universal development path. Different trajectories may co-exist, depending on sector- 
and location-specific circumstances. This research is for us a way to question simple process and deterministic models of evolution of industrial districts that assume neat linear progressions of welldefined phases leading to well-defined outcomes (Langley, 1999).

Our analysis demonstrates that the industrial district is the result of a highly specific alchemy of social, political, family, cultural and economic factors associated with a particular region. During each period, the development of Technic Valley resulted from macro-economic control according to which external forces successively forged then disrupted the internal balance, forcing the local actors to transform and reorganize themselves. The relational structures within districts have thus changed over time as a result of unforeseeable events such as periods of economic crisis, or mergers and acquisitions of companies.

The industrial district we studied remains sustainable thanks to three different factors: in particular, differential growth, the embedded network of players within the region, the implementation of a system and the creation of new institutions resulted in the survival of the district.

\section{- A specific dynamic profile and differential growth.}

Throughout the course of the evolution Technic Valley, a number of "flagship" companies have arisen in the district as a result of differential growth. At the beginning of its history, this industrial district was of course not dominated by a group of firms, but the emergence of large firms during the most recent period led to progressive domination over the others. A distinction may thus be made between "core organizations" and supporting "subsidiary actors".

The differential growth of the district during its development can be interpreted as the adoption of international rules, particularly by the leading companies concerned with increased size, mergers and acquisitions and economies of scale. Contract-givers decided increasingly to adopt more formal relationships, with the accent firmly on price, in line with the economic principles of globalization.

- Reinforced cooperation between firms confronted with new pressures

As in other industrial districts, a number of informal institutions exist (family links, relations based on trust and a history of working together), but faced with the pressures of globalisation, the players 
involved opted to formalise these relationships and develop solidarity. While members of the district continue to insist on their traditionally competitive relationships, they are all too well aware that it is impossible to resist pressure as isolated units and they are thus developing collective bodies to organise cooperation.

In this respect, although the district is evolving towards a hierarchical structure, the changes are close to the type theoretically analyzed by Boschma and Lambooy (2002). The trajectory of Technic Valley is characterized by trust-based relationships between the leader-firms and their main suppliers, and by joint-problem solving.

We would stress here the fact that the evolution of the district, as a result of external events, does not fellow a sequential and linear progression of phases of embeddedness towards phases of disembeddedness, as many works tend to argue. Instead, we see a process of re-embeddedness.

\section{- Strengthening of embeddedness and institutionalisation as a response to external crises}

Our study shows a relation between increased pressure towards globalisation and the development of formal institutions for coordination. These formal institutions were developed in order to stabilise the field of play. As the pressure of globalisation increased, the players responded by greater organisation through the creation of formal institutions. In addition, the development of specialised training bodies highlights the preoccupation with preserving local know-how by maintaining a qualified local workforce. Contrary to the districts studied by Paniccia (1998), who observed that firms in districts often follow a strategy of staff poaching, the business strategy is based on cooperation in which training courses are collectively organized at the district level.

This analysis casts some doubt on research indicating disembeddedness of the districts and the tendency towards increased competition within local production systems as a result of the effects of globalization. Here intermediaries have not disappeared but have rather fostered a culture of trust and cooperation (Amin, 1999).

Our case study indicates that the upheaval caused by globalisation led the players within the industrial district to examine and reorganise their traditional practices in a more formal, institutionalised way. The first effect of this formalisation was to fix practices which, in order to 
become more durable, nevertheless fluctuated according to different times and economic circumstances. The second effect was due to the fact that the existence of these formal institutions determined the development of relationships within the district. By promoting the development of trust between companies, these formal institutions also developed cooperation. As they grew increasingly aware of the mutual benefits offered by resource sharing, companies became more willing to co-operate.

Finally, the answer provided by our case study to the research questions outlined at the start of the paper is that that the examination of change within an industrial district shows the absence of convergence towards a single model of disembeddedness. The changing nature of this district and its sustainability take the form of mechanisms of cooperation in the development of formal institutions, which then have a positive influence on the dynamics of strategies within the industrial district in response to external pressures such as globalisation. The article suggests that the creation of certain institutions by the local players resulted in the preservation and strengthening of local bonds, thereby reducing the risk of delocalisation. It also intimates that resistance to delocalisation and the development of a productive local fabric can in fact be organised by players within the private sector.

All of these results can be linked to policy debates as far as the evolution of industrial districts is concerned (Whitford, 2001). Our study highlights the historical complexities at work. It emphasizes the risk of ineffectiveness of public policies that do not take account of this complexity and these specificities. One possible suggestion is that the public authorities might become involved not in order to organise such districts from scratch but rather as a means of supporting local initiatives. 


\section{REFERENCES}

Amighini, A., Rabelotti R. 2006. How do Italian footwear industrial districts face globalization?. European Planning Studies, May, 14 (4): 485-502

Amin, A. 1999. The emilian model: institutional challenges. European Planning Studies 7 (4): 389-403.

Becattini, G. 1990. The Marshallian industrial district as a socio-economic notion. In Industrial Districts and Inter-Firm Cooperation in Italy, Eds. F. Pyke, G. Becattini, G. Sengenberger, W. 1990. 37-51, Geneva : International Institute for Labour Studies.

Becattini, G. 1991. Italian industrial districts: problems and perspectives. International Sudies of Management and Organization 21-1: 83-90.

Bellini, N. 2000. Planning the learning region: An Italian approach. In Knowledge, innovation and economic growth. The theory and practice of learning regions, ed. F. Boekema, K. Morgan , S.Bakkers, and R. Rutten, 95-114. Cheltenham: Edward Elgar.

Biggiero, L. 2002. The location of multinationals in industrial districts: knowledge transfer in biomedicals. Journal of Technology Transfer $27: 111-122$.

Boschma, R., Lambooy J. 2002. Knowledge, market structure and economic coordination: Dynamics of industrial districts. Growth and Change 33: 291-311.

Breschi, S., Malerba, F. 2001. The geography of innovation and economic clustering: some introductory notes. Industrial and Corporate Change 10-4: 817-833.

Brusco, S. 1990. The idea of the industrial district: its genesis in . In Industrial Districts and Inter-Firm Cooperation in Italy, Eds. F. Pyke, G. Becattini, G. Sengenberger, W. 1990. 10-19, Geneva : International Institute for Labour Studies.

Campbell, J.L., Pedersen. 2001. The Rise of Neoliberalism and Institutional Analysis, Princeton University Press.

Camuffo, A. 2003. Transforming industrial districts: large firms and small business networks in the Italian Eyewear Industry. Industry and Innovation 10-4: 377-401.

Courlet, C., Léger, J-C. 1998. L'exemple de la vallée de l'Arve Séminaire CGP-Dares, Paris, 6-7 April.

Coro, G. \& Grandinetti, R. 1999. Opening-up Networks and Institutional Change in Industrial Districts: a Survey in the Italian Case. $11^{\text {th }}$ International Meeting on Socio-Economics, University of WisconsinMadison, USA, July 8-11

Dei Ottati, G. 1994. Cooperation and competition in the industrial district as an organization model. European Planning Studies 2: 463-483

Dunford, M. 2006. Industrial districts, magic circles and the restructuring of the Italian textiles and clothing chain. Economic Geography Jan 82 (1): 27-59

Ganne, B. 1991. Les approches du local et des systèmes industriels locaux. Esquisse de bilan critique du camp français. Sociologie du travail 4: 545-576.

Grabher, G. 1993. The weakness of strong ties: a network theory revisited In The Embedded Firm Ed. G. Grabher. Routledge: London.

Held, D. McGrew, A. Goldblatt, D., Perraton, J. 1999. Global Transformation. Politics, Economics and 
Culture. Cambridge University Press.

Langley, A. 1999. Strategies for theorizing from process data. Academy of Management Review. 24-4: 691710.

Lazerson, M. Lorenzoni, G. 1999. The firms that feed industrial districts: a return to the italian source. Industrial and Corporate Change. 8-2: 235-250

Lechner, C., Dowling, M. 1999. The evolution of industrial districts and regional networks: the case of the biotechnology region Munich/Martinsried. Journal of Management and Governance. 3: 309-338.

Lorenzen, M. Mahnke, V. 2002. Global Strategy and the Acquisition of Local Knowledge: How MNCs enter Régional Knowledge Clusters. Working Paper. Copenhagen Business School.

Markusen, A. 2003. Fuzzy concepts, scanty evidence, policy distance: the case for rigour and policy relevance in critical regional studies. Regional Studies 77-6/7: 701-717.

Mistri, M., Solari, S. 2002. Behavioural Rules in Industrial Districts: Loyalty, Trust and Reputation. Working Paper, Department of Economics, University of Padova, Italy.

Molina-Morales, F.X. Lopez-Navarro, M.A. Guia-Julve, J. 2002. The role of local institutions as intermediary agents in the industrial district. European Urban and Regional Studies. 9-4: 315-329.

Nassimbeni, G. 2003. Local manufacturing and global economy: Are They Compatible? The Case of the Italian Eyewear District. Journal of Operations Management 21-2: 151-172.

Paniccia, I. 1998. One, a hundred, thousands of industrial districts: Organizational variety in local networks of small and medium-sized enterprises. Organization Studies 19-4: 667-699.

Perez-Aleman, P. 2005. Cluster formation, institutions and learning: the emergence of clusters and development in Chile. Industrial and Corporate Change. 14-4: 651-677.

Phelps, N.A. Waley, P. 2004. Capital versus districts: a tale of one multinational company's attempt to disembed itself. Economic Geography 80-2: 191-216.

Piore, M. Sabel, C. 1984. The Second Industrial Divide. New York : Basic Books.

Porac, J., Thomas, H., Baden-Fuller, C. 1989. Competitive groups as cognitive communities: the case of Scottish Knitwear Manufacturers. Journal of Management Studies 26-3: 397-416.

Puthod, D. 1995. Entre confiance et défiance: la vigilance au cœur de la gestion des alliances. Gestion 20002 : 111-129.

Pyke, F. Becattini, G. Sengenberger, W. (Eds.) 1990. Industrial Districts and Inter-Firm Cooperation in Italy. Geneva : International Institute for Labour Studies.

Rama, R. Ferguson, D. Melero, A. 2003. Subcontracting networks in industrial districts: The electronic industries of Madrid. Regional Studies February 37-1: 71-89.

Reverdy, B. 2001. Accompagnement et territoire. $7^{\text {th }}$ annual seminar of the Department of Company Statistics of INSEE, 6 December.

Scholte, J.A 2000. Globalization: A Critical Introduction. Basingstoke/New York: Palgrave.

Scott, A. 1998. Regions and the world economy: The coming shape of global production, competition, and political order. Oxford: Oxford University Press.

Scott, A. 2006. Geography and Economy. Oxford : Oxford University Press. 
Scott, A. Storper M. 2003. Regions, globalization, development. Regional Studies. 37-2: 579-593.

Storper, M. 1997. The regional world. Territorial development in a global economy. New York : Guilford Press.

Whitford, J. 2001. The decline of a model? Challenge and response in the Italian industrial districts. Economy and Society 30-1: 38-75.

Yin, R. 1989. Case Study Research: Design and Methods. London : Sage. 